化礉素の添加量の增加と共にアルカリの最遮量が增加し, 酸化矹 素の添加㽬が或一定量を超すとアルカリの最迹量が急激に著しく 堽加し，酸化硼素とアルカリとの間には一定の量的閣係か認めら れない。(4) 固形バラフィンの如き高分子量炭化水素の生成を抑 制し館和炭化水素の生成を促進する。反對にアルカリは高分子量 炭化水素の生成を促進し飽和炭化水素の生成を抑制する。之等の 結果から酸化嗍素の作用はアルカリと密接な關係を有するが, 酸 化硼素はアルカリと一定の樣式に結合して作用するものではなく 個々の形で夫々獨特の作用を有しこの 2 種の作用が綜合されて 强力な石油合成能力を與へるものと考へられる。鐵触媒に對する 酸化硼素とアルカリの活性促淮作用の機構に就ては倘他方面から 詳細な研究を行つて居り改めて考察する積りである。

香も角著者等は前報及び本報の研究によつて鐡触媒に對して矹 素が極めて骤秀な活性促進作用を有することを發見し， $\mathrm{CO}: \mathrm{H}_{2}$ $\cong 1: 1$ の原料ガスを用ひて1四の通過によりその $1 \mathrm{~m}^{\mathrm{a}}$ より 144 〜 145 cc の合成油を得ることに成功した。この油收量は鐵觸媒に

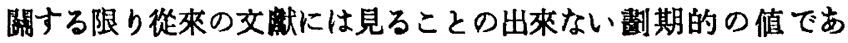
ろ。鐵を主體とした触媒を使用する時はコバルト或はニッヶル觝 媒の場合と異り,水の代りに主として炭酸ガスが副成する雼, 原料 ガス中の一酸化炭素と水素の消费制合は略々 2.0 1.5: 1 となり, 原料がスとして CO: $\mathrm{H}_{\mathbf{3}} \cong 1: 1 の$ のを使用する時は有效ガス含 量は 75 83\% である（第 47 報, 本誌, 昭和 14, 42, 204)。著 者等の一人村田は常岡氏と協力して $(50 \% \mathrm{Ni}+50 \% \mathrm{Co})+20 \%$ $\mathrm{Mn}+20 \% \mathrm{U}_{3} \mathrm{O}_{8}+125 \%$ 进藻土なる組成の $\mathrm{Ni}-\mathrm{Co}$ 二元觸媒によ b $\mathrm{CO}: \mathrm{H}_{2} \cong 1: 2$ の原料を用ひて $179 \mathrm{cc} / \mathrm{m}^{8}$ の合成油を得たが この場合には一酸化炭素と水素か消費率と咯々同等な割合にある 原料ガス（郎ち有效ガス含最䄪 100\%) を使用したのである(第 39 報, 本誌, 昭和 $13,41,95$, 㟬驗 $\mathrm{M} 17 \mathrm{~b}$ )。 $\mathrm{CO}: \mathrm{H}_{2} \cong 1: 1$ の

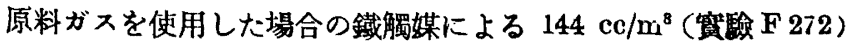
及び $145 \mathrm{cc} / \mathrm{m}^{8}$ （賽驗 F 276） なる油收量は有效ガス $1 \mathrm{~m}^{8}$ に就て 見れば夫ょ $144 \mathrm{cc} / \mathrm{m}^{8} \times \frac{100}{49.0+49.0 \times 0.67} \div 176 \mathrm{cc} / \mathrm{m}^{8}$ 及び 145 $\mathrm{cc} / \mathrm{m}^{8} \times \frac{100}{49.3+49.3 \times 0.65} \div 178 \mathrm{cc} / \mathrm{m}^{\mathrm{s}}$ となり油收量に關する限り 從來の $\mathrm{Ni}, \mathrm{Co}$ 或は $\mathrm{Ni}-\mathrm{Co}$ 系解媒と何等遜色がないのである。 上記 $\mathrm{Ni}-\mathrm{Co}$ 系二元觸媒の場合に得大油收量 $179 \mathrm{cc} / \mathrm{m}^{8}$ の资㯺に 於ては原料ガス中の一酸化炭素及び水素の消費本は夫↔ $92.5 \%$ 及び $94.2 \%$ であるが鐵䚡媒の場合は $88.8 \%$ 及び $58.3 \%$ (油收 量 $144 \mathrm{cc} / \mathrm{m}^{8}$ の時) 並に $86.6 \%$ 及び $55.8 \%$ (油收量 $145 \mathrm{cc} / \mathrm{m}^{8}$ の時）となつて居り，鐵觸媒の場合には副反應が少く油の收量は $\mathrm{CO}: \mathrm{H}_{2} \cong 1: 1$ の原料ガスを使用しても尖增加することが出來る すのと思考される。

要するに以上の研究により矹素化合物及びアルカリを助解媒と して同時に添加することによつて鐵觸媒の活性は著しく增加し油 收量に關しては Ni 及び Co 系䚡媒に決して分らぬ良結果力:得ら れ，鐵觸媒の從來の致命的缺陷を完全に一掃することか泏來た。 著者等は鐵觸媒の工業化を促進する第硼素化合物及びアルカリ添 加鐵觸媒に就てその耐久性, 反應溫度等に關する詳細な研究を行 ひ幾多の興味ある事實を哦見した。之等の結果に就ては追て報告 ナる積りである。<smiles>[14CH3]</smiles>

（1）前報に引繏き鐵觸媒に對する矹素の作用を明にする第各種 の硼素化合物の添加の影響を研究した。（2）硼酸マンガン及び硼 酸マグネシウムの如き一般硼素化合物は矹酸と同樣の作用を有す る。（3）明素化合物は機械的混合によつて添加してすその效果を 充分に發揮する。（4）アルカリは機成的混合によつて添加した場 合はその效果を全然發揮せず触媒表面に政密に分布せしめるこ之 か絶對に必要である。(5) 無水唧酸を添加した場合に於ても一般 矹素化合物之同樣な效果が認められ，硼酸等の作用力揲媒表面の 單なる物理的性質の数化によるものではなく矹素自體の化學的作 用によるものであることを明にした。（6）鐵觸媒に對寸る朋素の 作用を總括しその活性促進作用に就て考察した。

本研究の一部は日本學街振興會捘助金を以て行つたものである。 问會に對して感謝の意を表する。

\title{
(196) 天日鹽田苦汁の組成に就て
}

岡俊平・稻 垣 春 雄

\section{緒 言}

海水を蒸登濃樎して食監を探收すると，母液として,ナトリウム マグネシゥム，カリウムの整化物，硫酸息化物を主成分とす

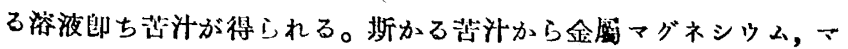

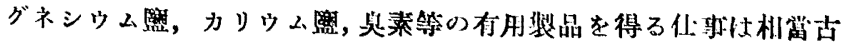

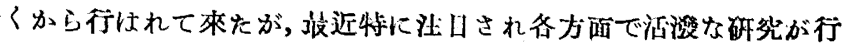

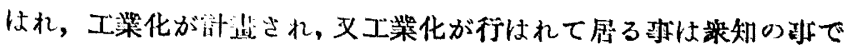
むる。

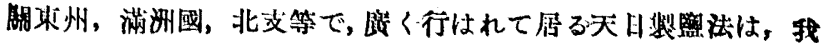

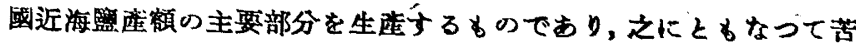

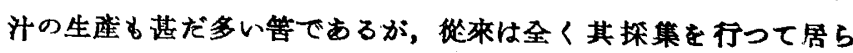
なかつた。所が近時，苦汁工業の重要性が垥すをとるに，其探

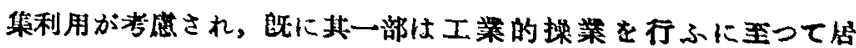
万。

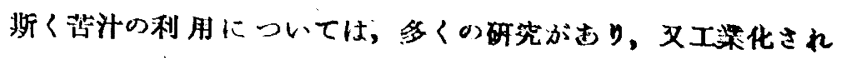

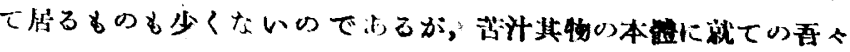

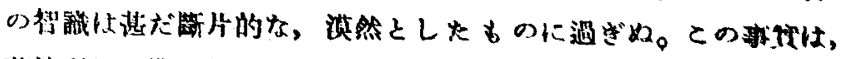

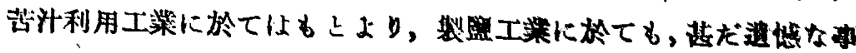
と思心。 
第 1 表 關東州苫汁 9 組成

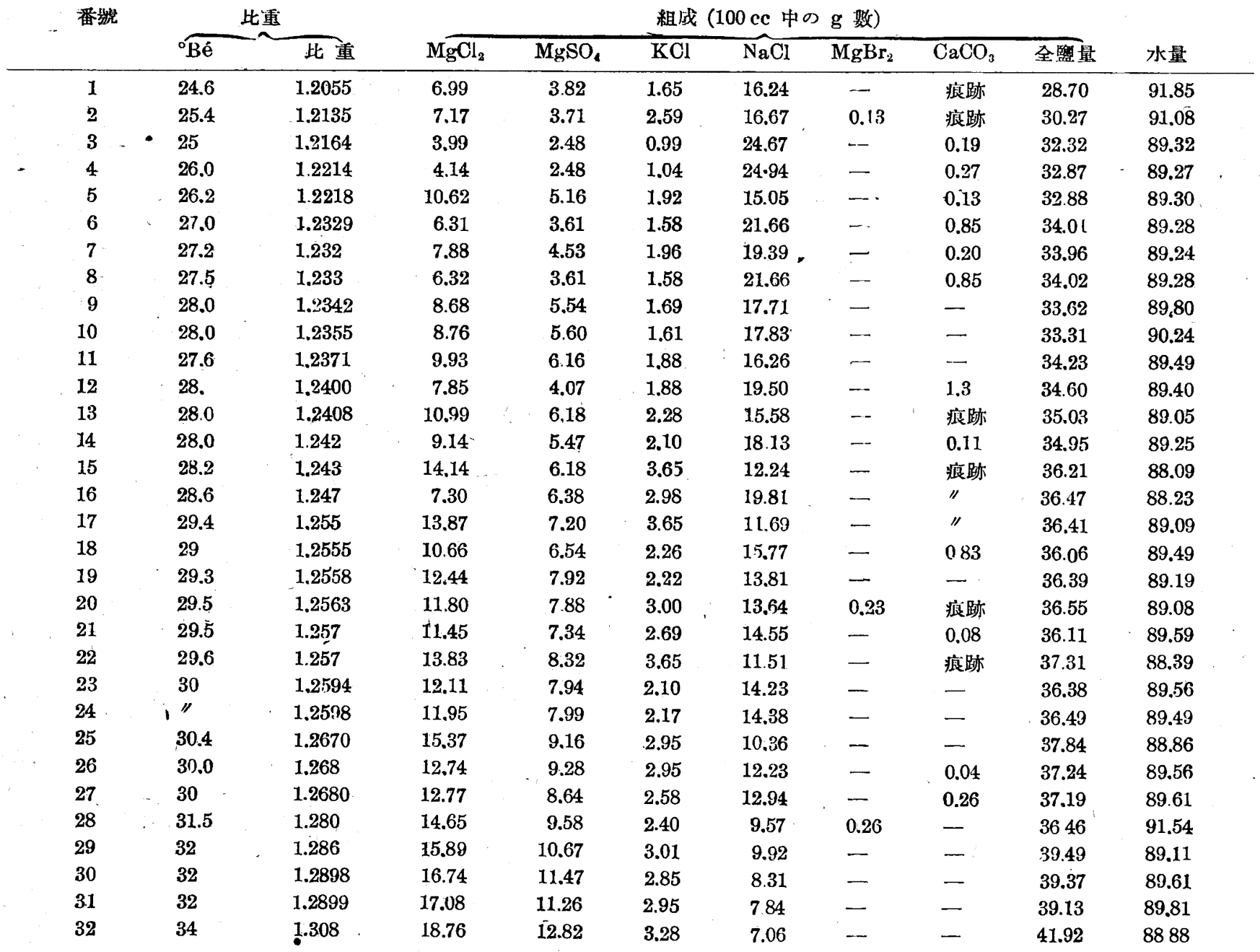

著者は最近閆東州, 滿洲國及び北支の各方面の研党者, 技術者諸 君の御好意により，天日䣯田苦计の分析結果 60 餘を輯集し得た。 本緑は是等の結果に，著者自身の若干の分析結果を加一て比較考

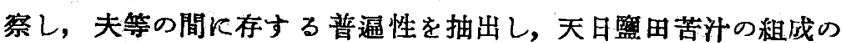

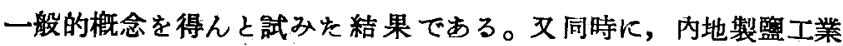
に於て行はれて居る煎整監の苦汁との關保を子明汃にせん之試み た。是等の結果が, 少しでる苦汁工業, 製監工業の發展槣與す る事が出來れば，著者の喜び之に過ぐるものはない。

\section{天日監田苦汁の組成}

輯集した分析結果は何れも苦汁を，鼍化マグネシウム，硫酸、

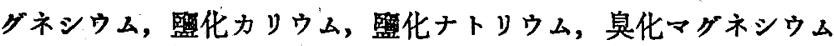
（時には臭化ナトリウム）及び硫酸カルシゥムの混合溶夜と し, 各成分の含量を重量百分率又は $100 \mathrm{cc}$ 中の $\mathrm{g}$ 數で表して 居る。

この二つの表し方の內, $100 \mathrm{cc}$ 中の $\mathrm{g}$ 數を用ひる方が多いの で, 全部をこの表し方に換算して比較する事にした。

苦汗組成を關東州，滿洲國及び北支の座地別に，比重の順に列 へたものを，第 1 表，第 2 表及び第 3 表に示した。分析結果の 中には, 比重とボーメ度の間に若干の食ひ違いのあるものも見出 されるし, 又比重と組成を照し合は寸と，少し誤りがありはせぬ かと思はれるおのもあるし, 實在し得ないと思はれる樣な組成の
ものもある。而し是等はすへてて其ま〉表に大れ取捨選擇を行はな かつた。先入主の䉆に，眞實を見失はん事を恐れたからである。

\section{苦汁の比重に就て}

第3 表を見ると，苦汁の比重は 1.155 1.342 に涉つて居る。 ボーメ度を以て示すと $19.0^{\circ}$ から $36.8^{\circ}$ に及んで居る。而し大 部分は 1.20〜1.31 の間, 郎ち $24^{\circ} \mathrm{Bé} \sim 34^{\circ} \mathrm{Bé}$ の間にある事が見 出される。

\section{第 2 表 滿洲國營蓋槛田苦汁の粗成}

\begin{tabular}{|c|c|c|c|c|c|c|c|c|}
\hline \multirow[t]{2}{*}{ 番號 } & \multicolumn{2}{|c|}{ 比重. } & \multicolumn{6}{|c|}{ 租戌(100 cc 中の $g$ 数) } \\
\hline & ${ }^{\circ} \mathrm{Bé}$ & 此重 & $\mathrm{MgCl}_{2}$ & $\mathrm{MgSO}_{4}$ & $\mathrm{KCl}$ & $\mathrm{NaCl}$ & 全監量 & 水量 \\
\hline 33 & 29.7 & 1.260 & 19.87 & 6.42 & 4.20 & 6.14 & 36.63 & 89.37 \\
\hline 34 & 30.1 & 1.264 & 18.59 & 6.73 & 2.40 & 8.68 & 36.40 & 90.00 \\
\hline 35 & 30.2 & 1.265 & 23.70 & 5.71 & 3.65 & 5.24 & 38.30 & 88.20 \\
\hline 36 & 30.5 & 1.268 & 23.25 & 6.80 & 2.91 & 5.66 & 38.62 & 88.18 \\
\hline 37 & 30.6 & 1.270 & 23.29 & 6.88 & 1.34 & 2.68 & 34.19 & 92.81 \\
\hline 38 & 31.1 & 1.275 & 15.70 & 13.19 & 3.39 & 10.28 & 42.56 & 84.94 \\
\hline 39 & 31.2 & 1.276 & 31.72 & 3.32 & 2.85 & 0.48 & 38.37 & 89.23 \\
\hline 40 & 31.5 & 1.280 & 19.90 & 9.31 & 3.61 & 6.25 & 3907 & 88.93 \\
\hline 41 & 33.4 & 1.301 & 28.48 & 9.18 & 3.69 & 0.43 & 41.78 & 88.32 \\
\hline 42 & 36.8 & $1.3 \pm 2$ & 28.08 & 7.95 & 3.61 & 2.40 & 42.04 & 92.16 \\
\hline
\end{tabular}


第 3 表 北支長盛監田苦汁の組成

\begin{tabular}{|c|c|c|c|c|c|c|c|c|c|}
\hline \multirow[t]{2}{*}{ 番㩆 } & \multicolumn{2}{|c|}{ 比重 } & \multicolumn{7}{|c|}{ 租成 (100 cc 中の $g$ 數) } \\
\hline & ${ }^{\circ} \mathrm{Bé}$ & 比重 & $\mathrm{MgCl}_{2}$ & $\mathrm{MgSO}$ & ${ }_{4} \mathrm{KCl}$ & $\mathrm{NaCl}$ & $\mathrm{MgB}$ & & 小浯 \\
\hline 3 & 190 & 1.155 & 4.27 & 2.52 & 0.75 & 12.48 & 0.85 & 20.87 & 94.64 \\
\hline 44 & 235 & 1.195 & 7.56 & 4.07 & 1.11 & 13.58 & 0.13 & 26.45 & 93.05 \\
\hline 45 & 28.8 & 1.250 & 14.68 & 6.25 & 3.08 & 10.88 & 0.30 & 35.19 & 89.81 \\
\hline 46 & 29.5 & 1.258 & 27.53 & 1.06 & 298 & 6.57 & 0.30 & 38.44 & 87.36 \\
\hline 7 & 30.0 & 1.262 & 20.13 & 8.26 & 2.56 & 5.54 & $\cdots$ & 36.49 & 89.71 \\
\hline 8 & 30.0 & 1.262 & 21.07 & 8.48 & 3.04 & 4.32 & - & 36.91 & 89.29 \\
\hline 9 & 30.0 & 1.263 & 16.06 & 6.50 & 3.04 & 9.94 & 0.35 & 35.89 & 90.41 \\
\hline 50 & 30.9 & 1.273 & 20.83 & 7.87 & 2.88 & 4.34 & 0.33 & 36.25 & 91.05 \\
\hline 51 & 31.0 & 1.275 & 15.74 & 8.03 & 2.14 & 12.08 & 0.22 & 38.21 & 89.29 \\
\hline 2 & 31.2 & 1.276 & 14.57 & 7.08 & 2.50 & 13.82 & 0.32 & 38.29 & 89.37 \\
\hline 3 & 31.8 & 1.283 & 15.98 & 6.97 & 2.94 & 13.39 & 0.33 & 39.61 & 88.69 \\
\hline 4 & 32.0 & 1.285 & 22.91 & 7.20 & 3.00 & 4.25 & & 37.74 & 90.76 \\
\hline 5 & 32.2 & 1.287 & 24.12 & 7.95 & 3.02 & 3.94 & 25 & 39.28 & 89.42 \\
\hline 6 & 32.4 & 1.290 & 20.76 & 7.04 & 3.01 & 8.61 & 0.43 & 3988 & 89.12 \\
\hline 7 & 32.5 & 1.291 & 18.64 & 7.97 & 3.02 & 11.46 & 0.33 & 41.42 & 87.68 \\
\hline 8 & 32.8 & 1.294 & 32.27 & 6.65 & 2.56 & 211 & 0.39 & 43.98 & 85.42 \\
\hline 59 & 33.0 & 1.297 & 27.33 & 7.07 & 3.62 & 3.64 & 0.39 & 42.05 & 87.65 \\
\hline 60 & 33.0 & 1.297 & 26.66 & 6.44 & 4.46 & 3.49 & 0.53 & 41.58 & 88.12 \\
\hline 61 & 330 & 1.298 & 26.71 & 6.43 & 4.47 & 3.68 & 0.54 & 41.83 & 87.97 \\
\hline 2 & 33.3 & 1.300 & $25.9 ?$ & 7.46 & 1.82 & 4.29 & 0.40 & 39.89 & 9011 \\
\hline & 33.7 & 1.305 & 26.63 & 8.00 & 3.28 & 2.60 & 0.40 & 40.91 & 89.59 \\
\hline 4 & 33.7 & 1.306 & 23.73 & 9.42 & 3.17 & 4.55 & - & 40.87 & 89.73 \\
\hline 5 & 34.0 & 1.308 & 27.30 & 7.52 & 4.01 & 3.30 & 0.54 & $4 \grave{2} .67$ & 88.13 \\
\hline 66 & 34.0 & 1.308 & 30.43 & 6.33 & 3.22 & 1.98 & 0.51 & 42.47 & 88.33 \\
\hline 37 & 34.0 & 1.308 & 24.87 & 8.75 & 4.43 & 2.24 & 0.40 & 40.69 & 90.11 \\
\hline 38 & 34.0 & 1.308 & 27.31 & 7.56 & 4.02 & 3.28 & 0.54 & 42.71 & 88.09 \\
\hline 39 & 34.0 & 1.308 & 30.45 & 6.34 & 3.02 & 2.12 & 0.51 & 42.44 & 88.36 \\
\hline 0 & 34.0 & 1.308 & 25.20 & 7.54 & 4.02 & 5.89 & 1.09 & 4374 & 87.06 \\
\hline 1 & 34.0 & 1.308 & 27.93 & 6.46 & 3.02 & 5.22 & 1.02 & 43.65 & 87.15 \\
\hline 2 & 35.0 & 1.320 & 29.57 & 730 & 3.57 & 1.81 & 0.45 & 42.70 & 89.30 \\
\hline 3 & 35.0 & 1.320 & 25.03 & 6.56 & 4.51 & 6.18 & 1.10 & 43.38 & 88.62 \\
\hline
\end{tabular}

比重の小なるものは後に述べる樣に, 食覺の含量が大であつて むしろ战水と䊈すべく，斯かる苦汁を探集する事は有利でないと 思はれる。表中に出て居るものは, 恐らく探集後稀釋されたもの か, 又は試驗的に採集したものであらら。

比重の大なる方は,天日による蒸發能力により自ら限度がある。 關東州あたりの氣候では大體 1.29 程が其最大值と見てよいので
はないかと思ふ。それ以上の濃縮が行はれて居るのは, 特別の狀 况に於て起つたものと考へる。

\section{苦汁中の各成分の含量に就て}

水分の量 上述の表を通覽する時直に目につくのは, 其水分量 か略々一定で, 大體 $89 \mathrm{~g}$ 前後である事であら.ら。これは興味あ る事實と思ふ。

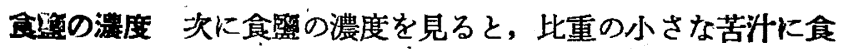
盬が多く含まれ，比重が大になると食殠濃度が小になる事か認め られる。

この關係を更に一目暸然たらしめる䉆に圖示すると, 第 1 圖の 樣になる。圖は橫軸に比重を探り, 縱軸に食監濃度を探る。圖中 ○印で示す點は關東州崖苦汁を示し，x印で示す點は滿洲國产，

○印で示す點は北支苦汁を示す。圖中の曲線は, 目测で最す よく關係を示すと考へる所へ引いたものである。

食監濃度は, 濃縮力淮み比重が㴰すと減少する事上述の通り である。從て, 若し一層高い比重まで濃縮されたものが, 何等 かの原因で稀䆁されたとすると, 食盟含量は比重に比して小くな る事と想像される。圖中甚しく下方に出てるる點は, 斯かる稀釋 された苦汁であらうと考へる。稀䆁による組成の變化には限りが 無いと思ふから, 之を除外する意味で目測で引いた曲線は、稀釋 されて居ら苦汁の組成を示す樣上の方に出て居る點に近く引い た。

監化マグネシウムの潩度 次に監化マグネシウム濃度を見る と, 比重が墳すにつれて濃度も大になつて居る事か認められる。 この關係を圖示すると, 第 2 圖の樣になる。

若し一旦濃縮されたものが，何等かの原因で稀釋されたとする と, 㽭化マグネシゥムの濃度は比重に相當するよりる大きくなる であららと想像される。圖中著しく上部に出て居る點は, 斯かる 稀釋された苦汁の點であらうと考へる。第 1 圖と第 2 圖とを對 照すると第 1 圖で下部に出て居る點は, 第 2 圖では上部に出て 居り, 上の推論の正しい事を示して居る。

硫酸マグネシウム濃度 硫酸 マグネシウムの濃度は, 比重の

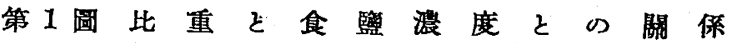

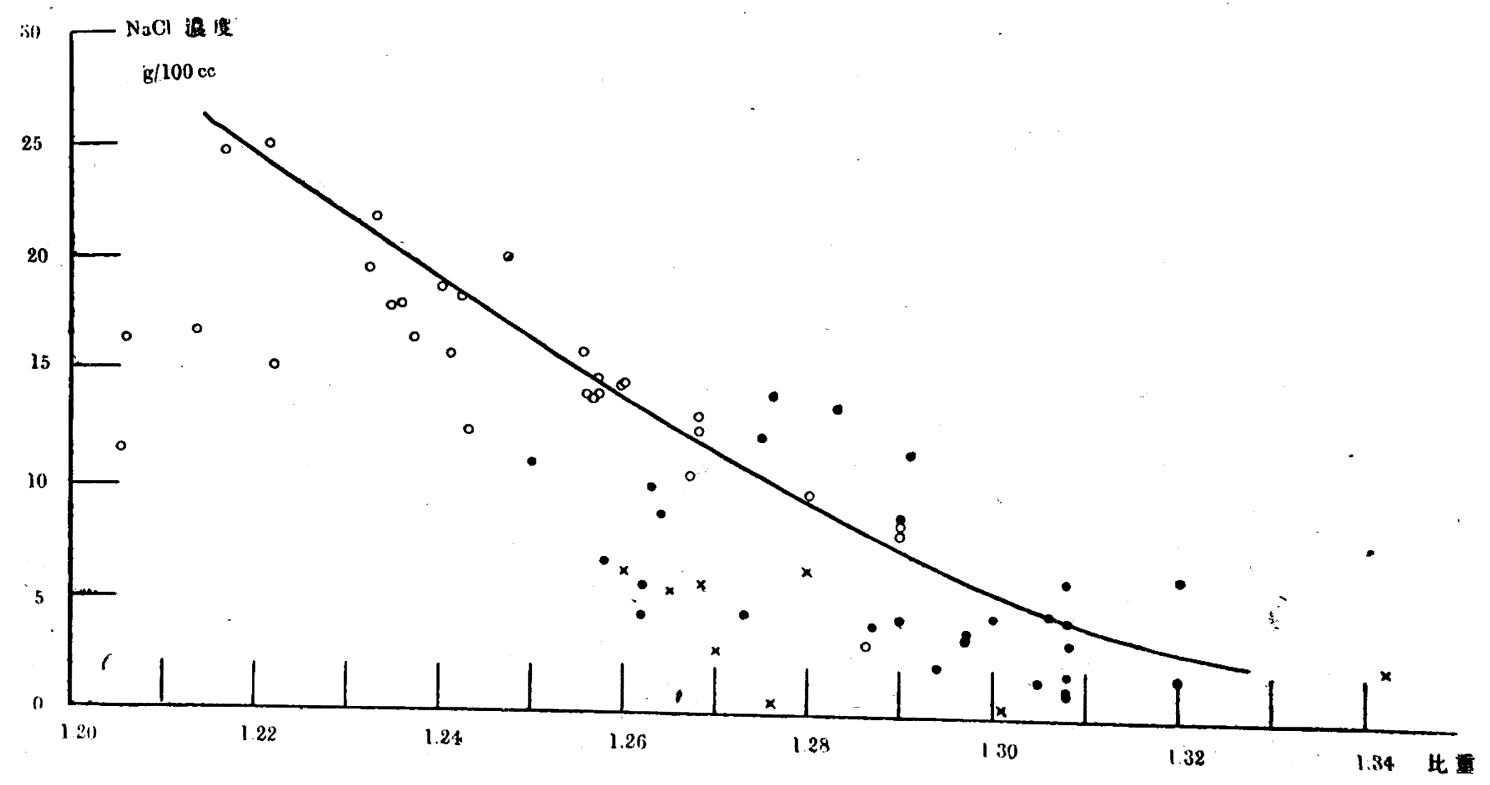


第 2 圖比重と敬化 $、$ グネシウム濃度との關係

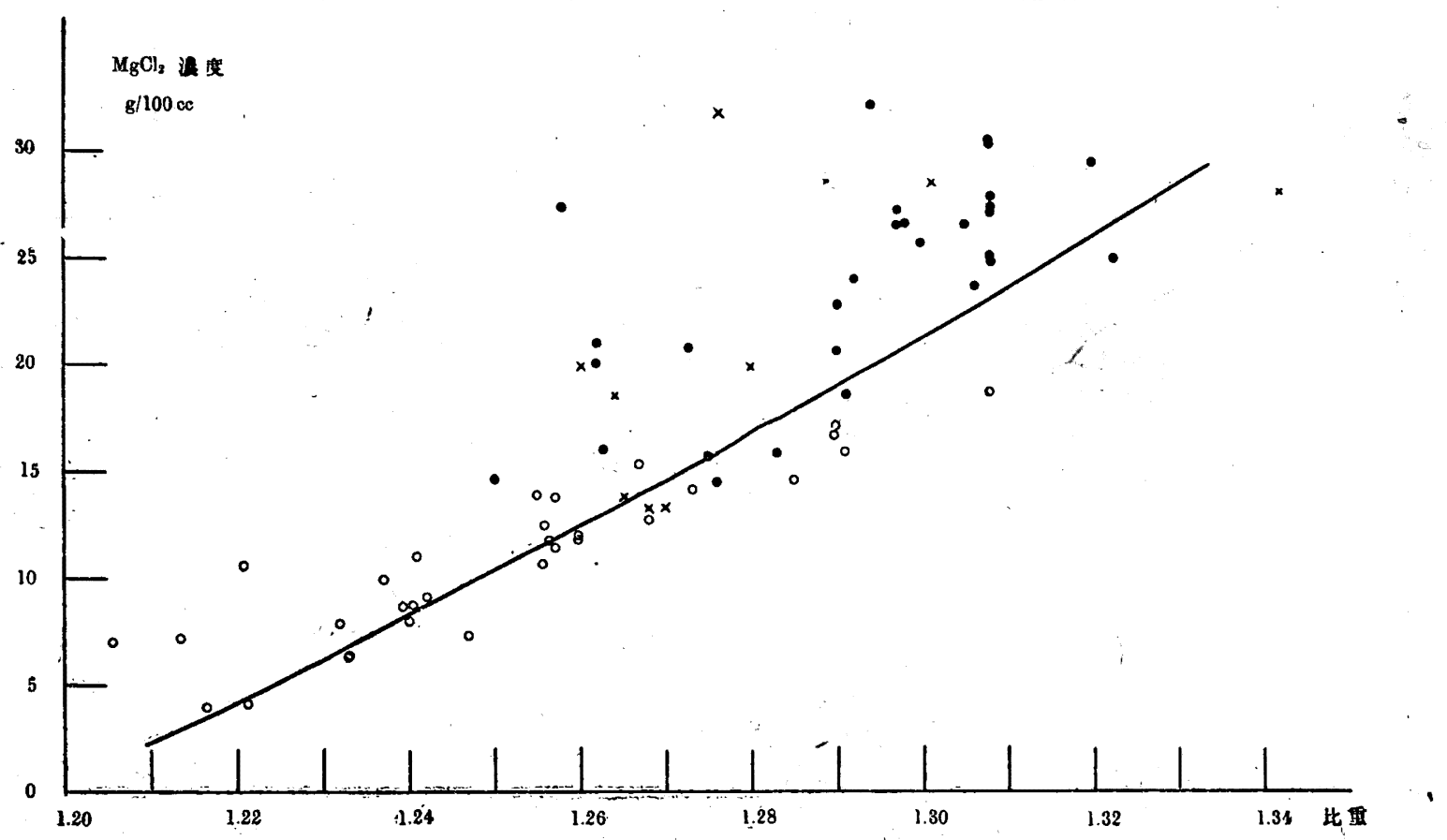

第 3 圖比重と硫酸マグネシウム濃度，との關保

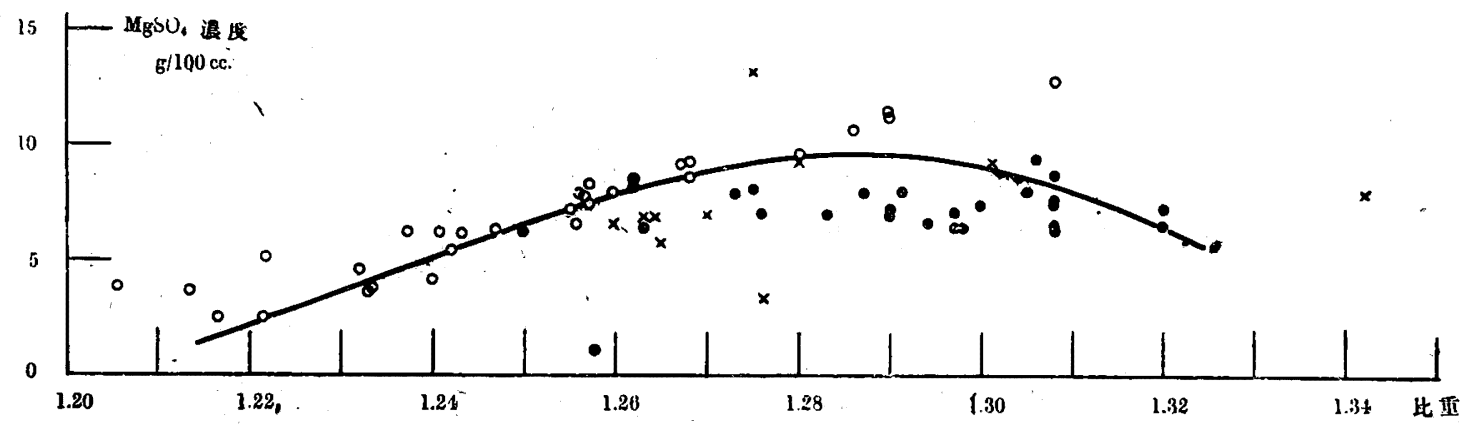

第 4 圖比重々監化カリウム浱度との關俰

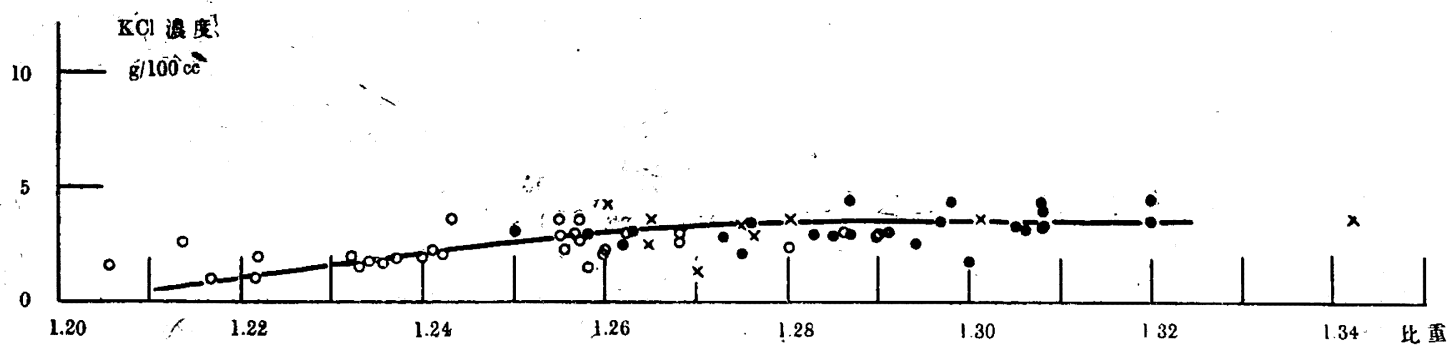

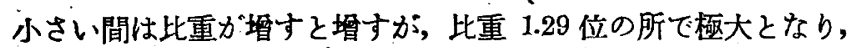
更に比重加增寸と却て減少して來る, この關倸は第 3 圖でよく 認められる。

監化カリウムの辳庋 監化カリウムの濃度は, 最初の問は比重 そともに增加して行くが，比重 1.28 前後で菂加が止り，それ以

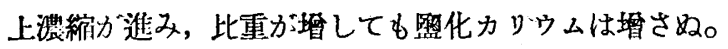

第 4 圆は是等の咸係を示す。最後に比重と各成分の含量との 關係を一括して第 5 圆に示した。この圆により,天日留田苦汁

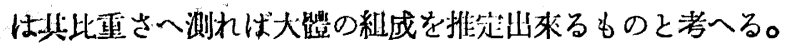

\section{産地による苦汁組成の特長}

次に表及び圖により座地による特長を見ると, 關東州㡾のもの が, 比較的小さな比重のものが多く, 營蓋及び長藍の苦汁には比

重の大きなものが多い事が認められる。

斯かる差異のよつて來る原因は, 恐らく土地の状海から起るも

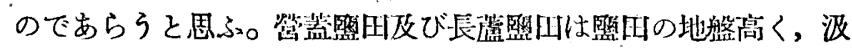

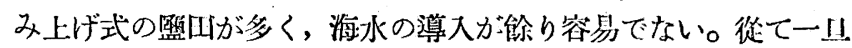

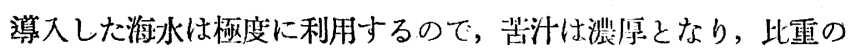

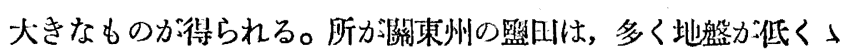




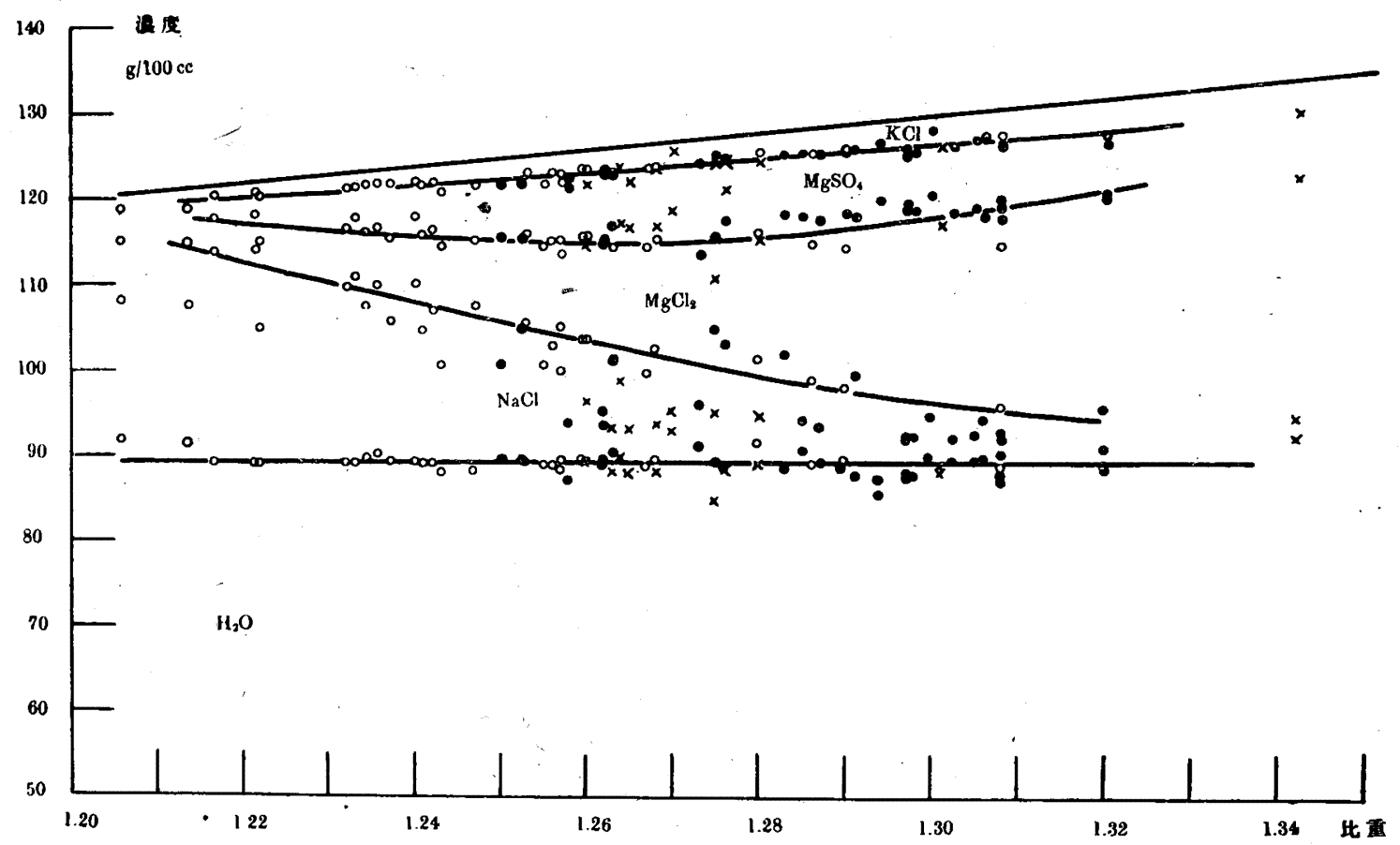

自然流下式であり, 海水の供給か潤澤であるから，蒸發は脰質に 惡影響を及ぼさぬ程度に止められ, 比較的稀いものとなり, 比重 が小さいのであらう。

又營蓋改び長嘘の籃田は滿人及び中華人の經營によるもの多

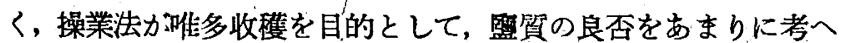
ない事も, 苦汁を濃厚にする原因であらう。關東州のものは, 何

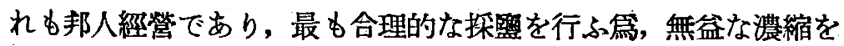
しないのであらら。

\section{煎謷監苦汁と天日鍳田苦汁との比較}

次に, 日本內地で行はれて居る樣な, 最後の蒸發を火力による

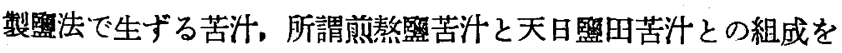

第 6 圖 煎整監苦汁の比重と組成の關保

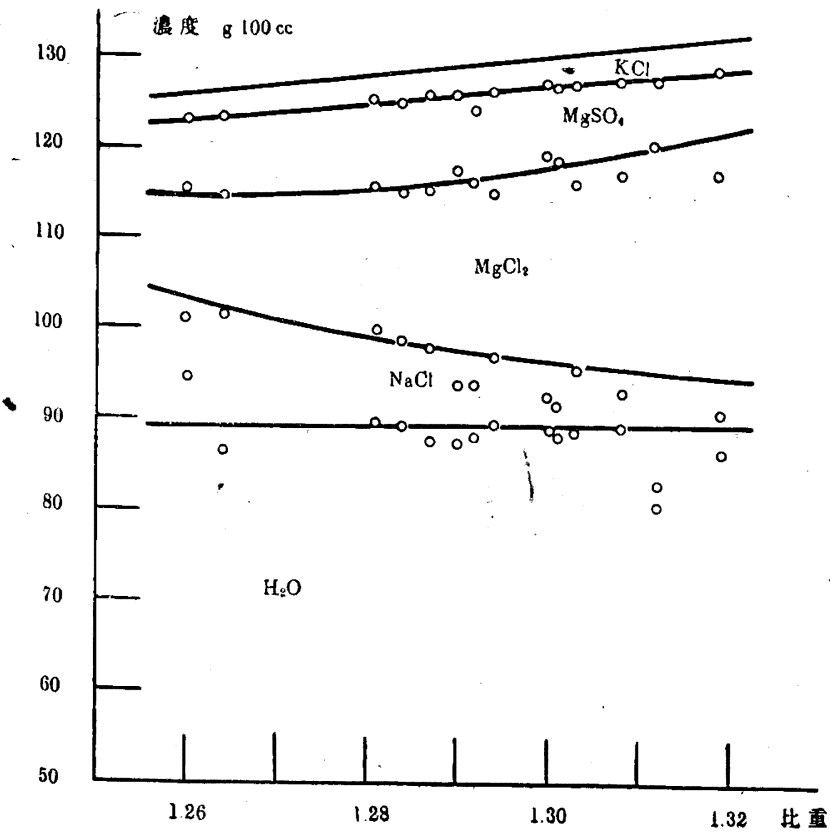

比較して見た。煎謷堅苦汁の組成は, 各種の單行本, 研究報告等 に記載されて居るものを集めた。結果を第 4 表に示す。是等の 值を第 1,2 及び 3 表の值と比較して見ると, 略々同樣のもの である事が認められる。結果を一目瞭然たらしめる篇に, 第 5 圖 と同樣の表し方をして見ると，第 6 圖の樣になる。圖中の曲線 は第 5 圖の曲線を, 其ま〉引いたものである。

第 4 表 煎謷留苦汁の粗成

\begin{tabular}{|c|c|c|c|c|c|c|c|c|c|}
\hline 番 & & 比重 & & & & $\mathbf{c}$ & 甲の $\mathrm{g}$ & & \\
\hline & ${ }^{\circ} \mathrm{Bé}$ & 比重 & $\mathrm{MgCl}_{3}$ & MgSO، & $\mathrm{KCl}$ & $\mathrm{NaCl}$ & $\underset{\text { 等 }}{\mathrm{MgBr}_{2}}$ & $\begin{array}{l}\text { 全監 } \\
\text { 望 }\end{array}$ & $\begin{array}{l}\text { 水 } \\
\text { 量 }\end{array}$ \\
\hline 1 & & 1.26 & 14.26 & 7.51 & 2.66 & 6.39 & 0.35 & 31.16 & 94.84 \\
\hline 2 & 30.1 & 1.264 & 13.31 & 8.65 & 2.83 & 15.02 & - & 39.81 & 86.59 \\
\hline 3 & & 1.281 & 15.72 & 9.74 & 3.19 & 10.20 & 0.60 & 38.45 & 89.65 \\
\hline 4 & & 1.284 & 16.47 & 9.80 & 2.97 & 9.57 & 0.63 & 39.44 & 88.96 \\
\hline 5 & 31.7 & 1.287 & 18.01 & 10.50 & 2.88 & 9.87 & - & 41.26 & 87.44 \\
\hline 6 & 32.4 & 1.290 & 23.6 & 8.5 & 3.2 & 6.3 & 0.5 & 41.6 & 87.4 \\
\hline 7 & & 1.292 & 22.27 & 8.04 & 4.50 & 5.78 & 0.64 & 41.23 & 87.97 \\
\hline 8 & & 1.294 & 18.03 & 11.41 & 3.17 & 7.29 & - & 39.90 & 89.50 \\
\hline 9 & & 1.30 & 26.8 & 7.8 & 3.0 & 3.8 & 0.7 & 41.4 & 88.6 \\
\hline 10 & & 1.301 & 26.84 & 7.86 & 2.99 & 3.77 & 0.76 & $42 . \dot{22}$ & 87.88 \\
\hline 11 & & 1.303 & 20.31 & 11.26 & 3.35 & 6.89 & $\cdots$ & 41.80 & 88.50 \\
\hline 12 & - & 1.308 & 24.17 & 10.16 & 3.77 & 3.78 & 一 & 41.88 & 88.92 \\
\hline 13 & & 1.312 & 37.58 & 7.15 & 2.61 & 2.51 & 1.31 & 51.16 & 80.04 \\
\hline 14 & & 1.319 & 26.31 & 11.50 & 3.69 & 4.35 & - & 4585 & 86.05 \\
\hline
\end{tabular}

この結果は一見意外の樣に思へる、天日照田の蒸發は30４0 等の比較的低溫で行はれるに對し，槊謷監の蒸は $100^{\circ} \mathrm{C}$ 以上の 高溫度で行はれる。從て苦汁の組成に著しい差が生じそラに思は れる。而しよく考へて見ると，苦汁の生成は成程高溫であるが, 苦汁の分析試料を探集寸るのは室盜近くに冷却してからに違ひな い。從て, 蒸發濃縮中は高溫の平衡に相當する組成を有して居て も，探集する時には低溫の平衙に相當する組成になつて居るので

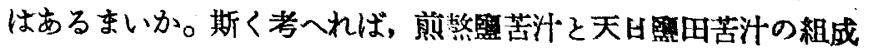
が同一であるのは當然と云へる。 


\section{結果に對する考察}

斯くて, 73 種の苦汁の分析結果の比較检討により, 天日辟仕 苦汁の組成の一般的概念办得られた之思ふ。是等の比較に於て, 可なり不規則な點も出て居るが，それ等の一部は苦汁探集後, 何 等かの原因で稀釋せられたものと考へると，硯明がつきそらに思 へる。この點については，他日實驗的に證明をしたとい思ふ。

比重と組成との關係を表す實驗式の製作も考へたが，採集後の 稀釋による變化は非常に不規則であるから，この變化なき點のみ を選んで計算をすべきだと思る。從て, 稀釋による變化を充分明 かにした後に行ふ事にしたい。

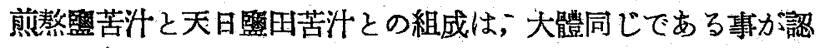
められた。從て以上の一般的關係は海水よりの苦汁全體に通ずる ゆのである。

\section{總括}

(1) 關東州，滿洲國及び北支の天日傿田苦汁 73 種の分析結 果を比較检討して，其一般的概念を得んと試みた。

（2）是等苦计の比重は $1.155 〜 1.942$ に涉つて居た。特に1.”0 〜 1.31 の間の物が多い。
(3)一比重と各種成分濃度との關係を求め次の結果を得た。郎 （イ） $100 \mathrm{cc}$ 中の水の $\mathrm{g}$ 數は, 比重と無關係に $89 \mathrm{~g}$ 前後にある。

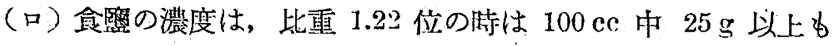
あるが，比重が大になると濑次減少し，1.30 位になると $5 \mathrm{~g}$ 程に

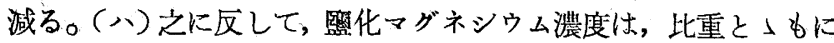
增加し, 1.22 で.4 $\mathrm{g}$ 程のものが, 1.30 では $20 \mathrm{~g}$ 以上になる。 (二) 硫酸マグネシウム濃度は, 1.22 の時 $2 \mathrm{~g}$ 程で, 比重が增す そ增すが，1.29 位の時を極大とし $10 \mathrm{~g}$ 位となり，それ以上比重

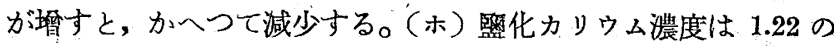
時 $1 \mathrm{~g}$ 程であるが, 此重が墦すと增し，1.28 位の特 $4 \mathrm{~g}$ 程とな り，それ以上比重が大となつでも濃度は增さぬ、

（4）座地別による特長を見ると, 關東州のものは比重小く, 满洲國及び北支のものは, 大きなるのが多い。其原因を考察し, 要するに土地の狀況によるものなる事を推定した。

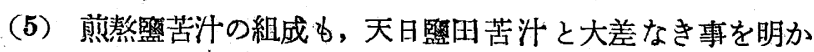
にした。

終りに臨み，本絽の分析結果を御惠與せられたる方々に深甚の 謝意定表する。

(商工省東京工業試驗所)（昭和 16 年 12 月 10 日受理）

(昭和 15 年 4 月第 4 包日本工學大會請演)

\section{(197 198）芒硝を原料とする炭酸ガス加壓アンモニア・ ソーダ法の相律的研究 (第 1 2 報)}

\section{队 \\ （第 1 報）岩酸ガス加壓下の $\mathbf{N a}_{2} \mathrm{SO}_{4}$ - $\mathrm{NH}_{4} \mathrm{HCO}_{3}-\mathrm{H}_{2} \mathrm{O}$ 互變系平衡}

\section{I. 緒 言}

現在, 我國飞於て消費される菏性ンーダの $50 \%$ 以上は人造瀻維 工業に使用され其大部分は艺碚として排出されてるる。我國の如人 原料監の量重な國情に在つては出來得る限りナトリウム基は國内 で偱環使用すへきであると思ふ。此研究は其一法として芷矿を原料 とするアンモニア・ソーグ法の基礎的部分を相律的に检討したもの である。近年,ソーダ工業と人造肥料工業とは原料上の密接な關聯 K就て泩目されてるるが此方法によれば重炭酸ン一がを得ると同 時に硫酸アンモニウムを得る事る出來る。從て此研究はてれ等雨工 業連慗上の一資料となり得ると思ふ。

芒码を原料とするアンモニア・ソーダ法はソ聯に天然艺确を原料 とする工場があるとの事であるが未だ 工業として一般的には行は れてるない。研究は相當古くから行はれ下記の報告を始め其他二, 三の報告がある。

西瀑恭助氏 (本誌, 大正 $9,23,25 ; 1015$ )

P. P. Fedotieff J. Koltunoff (7. anorg. allg. Chem, 1923, 130, 39)
音五

A. P. Belopolskiı̌, S. Y. Shpunt, M. T. Serbrenikova (.J. App'ïed Chem., (U.S.S.R.) 1934, 7, 669; 1935, 8, 195) 主として炭酸化工程の最終平衡を静力學的に檢討じをもので次 の如き互變 2 對監の平衡を檢討の對象としてるる。

$\mathrm{Na}_{2} \mathrm{SO}_{4}+2 \mathrm{NH}_{4} \mathrm{HCO}_{3} \rightleftarrows 2 \mathrm{NaHCO}_{8}+\left(\mathrm{NH}_{4}\right)_{2} \mathrm{SO}_{4}$

アンモニア・ソーダ法の跫操作に於ては重炭酸アンモニアは用ひ ずアンモニアと炭酸ガスとを別々に使用するが，最終本衡を檢討 する場合には十分此互變 2 對盟の本衡が役立ち得ると思子。

此系に對して炭酸がスの加掼を考虑に入れた研究は上記, 西濹氏 の研究のみである。文從來の研究結果の內最高のナトリウム轉化率 を得たのも同氏の結果で $40^{\circ} \mathrm{C}, 8.1 \mathrm{~atm}$ に於ける $77 \%$ である。此 轉化率は食嚳を原料とした場合より數\%劣つてるる。

$\mathrm{NaCl}-\mathrm{NH}_{4} \mathrm{HCO}_{3}-\mathrm{H}_{2} \mathrm{O}$ 互綎系 (以下 $\mathrm{NaCl}-\mathrm{NH}_{4} \mathrm{HCO}_{8}$ 系と略 稱する)に於て高壓炭酸がスを利用してナトリウム轉化秝を常法こ 比して数\%引き上げ得を事は既に著者（本誌，昭和 $15,43 ， 449$ ) が報告した所である。此考を $\mathrm{Na}_{2} \mathrm{SO}_{4}-\mathrm{NH}_{4} \mathrm{HCO}_{3}-\mathrm{H}_{2} \mathrm{O}$ 互戀系(以 下 $\mathrm{Na}_{2} \mathrm{SO}_{4}-\mathrm{NH}_{4} \mathrm{HCO}_{3}$ 系之略稱する) 飞適用して西澤氏の行はれ なかつた更に高厴，高溫の場合を研究したのが此研究である。

相律的に見ると此平衡も全く $\mathrm{NaCl}-\mathrm{NH}_{4} \mathrm{HCO}_{3}$ 柔平衡と同樣で

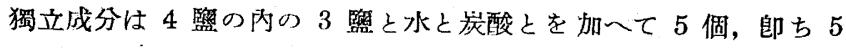
成分系の本矢である。從て研究方針は $\mathrm{NaCl}-\mathrm{NH}_{4} \mathrm{HCO}_{3}$ 系の場合 